\title{
Contrasting patterns of dissolved organic nitrogen release by two size fractions of estuarine plankton during a period of rapid $\mathrm{NH}_{4}{ }^{+}$ consumption and $\mathrm{NO}_{2}^{-}$production
}

\author{
Deborah A. Bronk*, Patricia M. Glibert \\ Horn Point Environmental Laboratory, University of Maryland, PO Box 775, Cambridge, Maryland 21613, USA
}

\begin{abstract}
Rates of $\mathrm{NH}_{4}{ }^{+}$uptake and total and low molecular weight ( $\mathrm{LMW} ;<10000$ Dalton) dissolved organic nitrogen (DON) release were measured on size-fractionated $(<202$ and $<1.2 \mu \mathrm{m})$ plankton. Water was collected from the Choptank River, a subestuary of Chesapeake Bay, USA, in August 1990 and contained for $36 \mathrm{~h}$ in large carboys. Periodically, samples were removed from each carboy, nutrient concentrations were determined, and the rates of $\mathrm{NH}_{4}{ }^{+}$uptake and total and LMW DON release were measured during $0.5 \mathrm{~h}$ incubations. Approximately $7 \mu \mathrm{g}$-at. $\mathrm{NH}_{4}{ }^{+}$were consumed in each carboy during the $36 \mathrm{~h}$ containment, and up to $6 \mu \mathrm{g}$-at. $\mathrm{NO}_{2}{ }^{-}$were produced, which suggests that nitrification was occurring. Rates of total DON release were significantly higher in the $<202 \mu \mathrm{m}$ plankton relative to the $<1.2 \mu \mathrm{m}$ plankton likely due to feeding processes, such as grazing, associated with the larger size fraction. Evidence for feeding-induced DON release in the <202 $\mu \mathrm{m}$ plankton includes the small ratio of LMW DON to total DON release, the increase in DON release rates at night, and the doubling of phaeopigment concentrations during the $36 \mathrm{~h}$ experiment. In contrast, in the $<1.2 \mu \mathrm{m}$ plankton, rates of LMW DON release were not significantly different from rates of total DON release and rates of DON release decreased by over $95 \%$ in the dark. In this case, we suggest that passive release from autotrophs was a more important release process.
\end{abstract}

\section{INTRODUCTION}

Dissolved organic nitrogen (DON) is often the most abundant form of dissolved nitrogen in marine ecosystems (Sharp 1983). Despite the large size of the pool and its potential importance as a nitrogen source, there is a lack of quantitative information on sources of the DON pool as a whole, largely due to methodological problems. The information we have on DON release is mostly a result of studies of individual compounds present in the DON pool, such as dissolved free amino acids (DFAA) or urea (reviewed by Antia et al. 1991), or from extrapolating information gained from studies of dissolved organic carbon (DOC) release (Sharp 1977). Seeking a more comprehensive measure of release of the large number of compounds which make

- Present address: Marine Science Program, University of California, Santa Cruz, California 95064, USA up the DON pool, Bronk \& Glibert (1991) applied a technique which involved labeling phytoplankton with ${ }^{15} \mathrm{~N}$ and then isolating any $\mathrm{DO}{ }^{15} \mathrm{~N}$ which may have been released. Using this technique in an experiment conducted in the mesohaline Chesapeake Bay, USA, during the decline of the spring bloom, we measured DON release rates ranging from undetectable to $0.17 \mu \mathrm{g}$-at. $\mathrm{N}^{-1} \mathrm{~h}^{-1}$ and found that release rates were heavily dependent on the source of nitrogen utilized, $\mathrm{NH}_{4}{ }^{+}$versus $\mathrm{NO}_{3}{ }^{-}$(Bronk \& Glibert 1991)

In the present study, we wanted to further investigate DON release from natural plankton populations, particularly from phytoplankton, traditionally considered the most important source of DON (Chan \& Campbell 1978, Billen 1984). Mechanisms of DON release involving phytoplankton include passive release, cell death and lysis, release during feeding or grazing by heterotrophs, and virus-induced lysis. We hypothesized that the relative importance of these 
different mechanisms would differ depending on the size and trophic structure of the plankton. For example, previous studies have shown that combinations of copepods and microplankton had a much higher release rate of DFAA then either one alone (Fuhrman 1987).

The objective of this study was to compare the rates of DON release of 2 size classes of plankton, $<202$ and $<1.2 \mu \mathrm{m}$, on the basis of the magnitudes of the rates, the molecular weight of the released material, and the temporal pattern of DON release. We have previously suggested that the molecular weight of released DON is indicative of the release mechanisms present (Bronk \& Glibert 1991). DON compounds released from phytoplankton range in molecular weight from large polysaccharides, nucleic acids and proteins to individual DFAA (Hellebust 1974, Billen 1984). Exudates passively released from actively growing phytoplankton, however, are dominated by low molecular weight (LMW) compounds (Hellebust 1965, Wiebe \& Smith 1977). In this study we sought to use the ratio of the rate of LMW DON to total DON release as an indicator of release processes. Further clues to the mechanisms of release were gained from the temporal patterns of release. For example, more of the DOC compound glucan is released in the light than in the dark (Azam et al. 1983) and some studies have shown that phytoplankton release of dissolved organic matter (DOM) in general is greatly reduced in the dark (Ward 1984).

The present study was performed with natural plankton assemblages collected during late summer from the Choptank River, a subestuary of Chesapeake Bay, where DON typically represents an average of 60 to $90 \%$ of the total dissolved nitrogen (J.C. Stevenson unpubl. data). In choosing size fractions, we wanted to separate grazers and associated feeding pracesses from direct release by phytoplankton and picoplankton. The overlap between grazers and phytoplankton, however, makes a clear separation impossible. We chose to use a $<1.2 \mu \mathrm{m}$ fraction, which likely contained small picoplankton, cyanobacteria, bacteria, and viruses, and $\mathrm{a}<202 \mu \mathrm{m}$ fraction which likely also contained larger phytoplankton, microheterotrophs, and microzooplankton (20-202 $\mu \mathrm{m}_{i}$ Brownlee \& Jacobs 1987, Dolan 1991). The microzooplankton in Chesapeake Bay are generally dominated by protozoa and rotifers though copepod nauplii, which have high carbon specific ingestion rates, are the most abundant members during August (Brownlee \& Jacobs 1987, White 1991). Several species of macrophagous and microphagous ciliates, including tintinnids and oligotrichs which are $<202 \mu \mathrm{m}$, have also been identified in surface waters in the mesohaline Chesapeake Bay during the summer (Dolan 1991) and may have been present in our samples. The size classes chosen for the study were influenced by a preliminary sizefractionation study which was performed in July 1989 with $<202,<10$, and $<1.2 \mu \mathrm{m}$ plankton taken from the Choptank River (unpubl. data). In this study, the $<202$ and $<10 \mu \mathrm{m}$ plankton behaved similarly with respect to rates of $\mathrm{NH}_{4}{ }^{+}$and $\mathrm{NO}_{3}{ }^{-}$uptake and the ${ }^{15} \mathrm{~N}$ atom\% enrichment of the DON pool; DON release rates were not directly measured.

\section{MATERIALS AND METHODS}

Experimental design. Surface water was collected from the Choptank River $(34 \mathrm{~km}$ from the mouth at $38^{\circ} 35^{\prime} \mathrm{N}$ and $76^{\circ} 05^{\prime} \mathrm{W}$ ) at dawn on August 14,1990 with a plastic bucket. The water was prefiltered through a $202 \mu \mathrm{m}$ Nitex mesh into two 201 carboys. One $20 \mathrm{l}$ carboy was further pressure-filtered through a $1.2 \mu \mathrm{m}$ Nuclepore filter using a $142 \mathrm{~mm}$ diameter Millipore filter tower; the concentration of $\mathrm{NH}_{4}{ }^{+}$, which we use as an indicator of cell breakage, did not increase after filtration through the $1.2 \mu \mathrm{m}$ filter. The carboys were incubated under in situ light and temperature conditions for $36 \mathrm{~h}$ and were shaken approximately every 2 to $3 \mathrm{~h}$ to keep the water well mixed and aerated. Aliquots $(1.1 \mathrm{l})$ were withdrawn from each carboy at 8 sampling periods $(0,1,3,6,12,24,30$, and $36 \mathrm{~h}$ ) and divided into 2 subsamples. One subsample $(100 \mathrm{ml})$ was used to measure the concentration of ambient nutrient and pigment concentrations, and the other subsample (1 1 1) was used to measure rates of $\mathrm{NH}_{4}{ }^{+}$uptake and total and LMW DON release using ${ }^{15} \mathrm{~N}$ tracer techniques.

Nutrient and pigment analysis. For the determination of DON, $\mathrm{NO}_{3}^{-}, \mathrm{NO}_{2}^{-}, \mathrm{NH}_{4}{ }^{+}$, and urea concentrations, water was filtered through precombusted $\left(450^{\circ} \mathrm{C}\right.$ for $2 \mathrm{~h}$ ) Whatman GF/F filters and frozen in acid-washed polyethylene bottles. Within a few days, the concentration of DON was determined by the method of Valderrama (1981), concentrations of $\mathrm{NO}_{3}^{-}$and $\mathrm{NO}_{2}^{-}$were determined using a Technicon AutoAnalyzer according to Parsons et al. (1984), and concentrations of urea and $\mathrm{NH}_{4}{ }^{+}$were analyzed manually with methods outlined in Parsons et al. (1984). In addition, water was filtered through a $0.2 \mu \mathrm{m}$ Nuclepore filter for later analysis of dissolved primary amine (DPA) concentrations (Parsons et al. 1984). A glycine standard was used in the DPA analysis and the values were corrected for fluorescence due to reaction with $\mathrm{NH}_{4}{ }^{+}$and urea.

Concentrations of chlorophyll a (chl) and phaeopigment were determined according to Parsons et al. (1984). Particulate nitrogen (PN) was analyzed by a Control Equipment CHN analyzer after filtration onto a precombusted Whatman GF/F filter. The pigment and PN analyses were done at the end of each ${ }^{15} \mathrm{~N}$ incubation. 
$\mathrm{NH}_{4}{ }^{+}$uptake and DON release rates. To measure rates of $\mathrm{NH}_{4}{ }^{+}$uptake and total and LMW DON release, additions of $0.66 \mu \mathrm{g}$-at. $\mathrm{N} \mathrm{I}^{-1}{ }^{15} \mathrm{NH}_{4}{ }^{+}$were made to subsamples (1 1) removed from each of the large carboys. Samples were incubated under in situ light and temperature conditions for $0.5 \mathrm{~h}$. At the end of the incubation, samples were further divided into 3 portions. The first portion $(300 \mathrm{ml})$ was used to measure rates of $\mathrm{NH}_{4}{ }^{+}$uptake. This portion was filtered through a precombusted GF/F filter which was subsequently dried at $50^{\circ} \mathrm{C}$, ampoulated, and analyzed by mass spectrometry (Nuclide 3" 60 sector mass spectrometer). The filtrate of this subsample was saved for analysis of the atom\% enrichment of the ${ }^{15} \mathrm{NH}_{4}{ }^{+}$pool as described by Glibert et al. (1982). When calculating the final $\mathrm{NH}_{4}{ }^{+}$ uptake rate we corrected the atom \% of the PN for the ${ }^{15} \mathrm{~N}$ lost to the DON pool using the following equation:

corrected at $\% \mathrm{PN}=$

$$
\frac{\left(\operatorname{mass}{ }^{15} \mathrm{~N} \text { in PN }\right)+\left(\text { mass }^{15} \mathrm{~N} \text { in } \mathrm{DON}_{\mathrm{e}}\right)}{[\mathrm{PN}]} \times 100
$$

where corrected at $\% \mathrm{PN}=$ atom $\%$ enrichment of the PN corrected for the ${ }^{15} \mathrm{~N}$ lost to the extracellular DON pool $[\mathrm{PN}]=$ concentration of $\mathrm{PN}$; and $\mathrm{DON}_{\mathrm{e}}=$ extracellular DON pool. To calculate $\mathrm{NH}_{4}{ }^{+}$uptake rates, we used the corrected atom $\% \mathrm{PN}$ in the equation derived by Dugdale \& Goering (1967) as modified by Glibert et al. (1982) for isotope dilution of the $\mathrm{NH}_{4}{ }^{+}$pool.

The second and third portions were used to measure the atom\% of the total and LMW extracellular DON pool and the phytoplankton intracellular LMW DON pool, respectively. To measure the atom $\%$ enrichment of the extracellular DON pool, $240 \mathrm{ml}$ of water was gently filtered $(<50 \mathrm{~mm} \mathrm{Hg}$ ) through a $0.2 \mu \mathrm{m}$ Nuclepore filter and the concentrations of $\mathrm{DON}, \mathrm{NH}_{4}{ }^{+}$, and $\mathrm{NO}_{3}{ }^{-}$were measured on the filtrate. In addition, $27 \mathrm{ml}$ of the filtrate was passed through ion retardation resin (BioRad AG $11 \mathrm{~A} 8$ ) to separate the $D O^{15} \mathrm{~N}$ from the added ${ }^{15} \mathrm{NH}_{4}{ }^{+}$as described in Bronk \& Glibert (1991); the resin attracts small charged molecules while allowing DON to pass. We neutralized the resulting eluate $(120 \mathrm{ml})$ to $\mathrm{a} \mathrm{pH}$ of 7 to 8 and separated $100 \mathrm{ml}$ and $20 \mathrm{ml}$ into 2 Erlenmeyer flasks. The eluates in the flasks were boiled down to approximately $2 \mathrm{ml}$. The $100 \mathrm{ml}$ sample was transferred to a precombusted Whatman GF/F filter which was dried and analyzed by mass spectrometry. We reconstituted the $20 \mathrm{ml}$ sample with distilled water and measured the concentrations of $\mathrm{DON}, \mathrm{NH}_{4}{ }^{+}$, and $\mathrm{NO}_{3}{ }^{-}$. The LMW DON was also isolated from this same sample by passing $45 \mathrm{ml}$ of the $0.2 \mu \mathrm{m}$ filtrate through a Centriprep ultrafilter (Amicon \#4305; 10000 Dalton molecular weight cut-off) prior to passing the filtrate $(27 \mathrm{ml})$ through ion retardation resin (Bronk \& Glibert 1991). On a number of samples, we isolated the organic nitrogen using GF/F filtrate in addition to the $0.2 \mu \mathrm{m}$ Nuclepore filtrate. The ${ }^{15} \mathrm{~N}$ in the GF/F filtrate represents both $D O^{15} \mathrm{~N}$ as well as ${ }^{15} \mathrm{~N}$ which was taken up by organisms $<0.7 \mu \mathrm{m}$.

To measure the atom $\%$ enrichment of the LMW DON within the intracellular pools of phytoplankton, the third portion $(300 \mathrm{ml}$ ) was passed through a precombusted Whatman GF/F filter. The filter was ground with trichloroacetic acid and centrifuged as described in Clayton et al. (1988). The supernatant was neutralized and then passed through a Centriprep ultrafilter (<10000 Dalton) and ion retardation resin as outlined above. The intracellular DON pool which is isolated contains heterotrophic and/or detrital organic nitrogen in addition to the DON in phytoplankton intracellular pools. We estimate the dilution of autotrophic organic nitrogen by heterotrophic and/or detrital nitrogen from the PN:chl ratio as described in Bronk \& Glibert (1991)

To calculate DON release rates we used equations analogous to those used by Dugdale \& Goering (1967) as described in Bronk \& Glibert (1991) with the following 2 modifications. First, the atom $\%$ of the intracellular DON pool was corrected for ${ }^{15} \mathrm{~N}$ lost to the extracellular DON pool during DON release. This correction is analogous to Eq. 1 used to correct the atom\% of the PN. Second, we corrected the extracellular DON atom $\%$ for contamination of ${ }^{15} \mathrm{~N}$-labeled $\mathrm{NH}_{4}{ }^{+}$which may not have been removed. Though we did not detect $\mathrm{NH}_{4}{ }^{+}$in the isolated DON fraction, the sensitivity of the $\mathrm{NH}_{4}{ }^{+}$analysis is only \pm 0.03 to $0.04 \mu \mathrm{g}$-at. $\mathrm{N}^{-1}$. We estimated the actual amount of $\mathrm{NH}_{4}{ }^{+}$in the isolated DON fraction from the $\mathrm{NH}_{4}{ }^{+}$concentration in the initial sample and empirically derived removal efficiencies of $\mathrm{NH}_{4}{ }^{+}$by the ion retardation resin and as a result of boiling as described in Bronk \& Glibert (1991). The following equation was used to calculate DON release rates:

DON release rate $=$

atom $\%$ excess extracellular DON pool

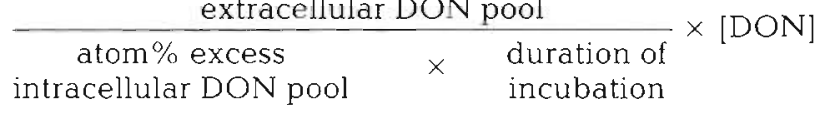

where atom\% excess of the extracellular and intracellular DON pool $={ }^{15} \mathrm{~N}$ atom $\%$ enrichment of the DON pool minus ${ }^{15} \mathrm{~N}$ atom $\%$ enrichment of the $\mathrm{N}_{2}$ standard; and $[\mathrm{DON}]=$ concentration of DON (total or LMW) within the incubation bottle at the end of the incubation.

Error analysis. Rates of $\mathrm{NH}_{4}{ }^{+}$uptake and DON release were not measured in duplicate due to the large amount of time required in sample processing and limitations in sample volume. To estimate the variability associated with the final rate measurements, a 
propagation of error analysis was performed as described in Bevington (1969). The variances of the nutrient concentrations and atom\% enrichments were calculated from replicates when available. When nutrient samples were not replicated due to limitations of sample volume, an estimate of the variance was calculated as described in Walpole (1970) using the variability associated with the regression line of nutrient standards which were used to calculate nutrient concentrations; this method provides a conservative estimate of the variance.

\section{RESULTS}

\section{Nutrient and pigment concentrations}

The Choptank River in late summer is a nutrient-rich system; the concentration of total nitrogen (particulate + dissolved ) we measured approached $60 \mu \mathrm{g}$-at. $\mathrm{N} \mathrm{I}^{-1}$ (Table 1). Of the total dissolved nitrogen, approximately $65 \%$ was in the form of DON (Table 1 ).

Large changes in nitrogen concentrations and fluxes were seen in both carboys during the 36 h experiment. In both carboys, $\mathrm{NH}_{4}{ }^{+}$was rapidly taken up and $\mathrm{NO}_{2}^{-}$ was produced. In the $<202 \mu \mathrm{m}$ plankton, all $7.6 \mu \mathrm{g}$-at. $\mathrm{N}^{-1}$ of $\mathrm{NH}_{4}^{+}$initially present was completely consumed by $30 \mathrm{~h}$ (Fig $1 \mathrm{~A}$ ). In the $<1.2 \mu \mathrm{m}$ plankton, however, only $89 \%$ of the initial $7.6 \mu \mathrm{g}$-at. $\mathrm{Nl}^{-1}$ of $\mathrm{NH}_{4}{ }^{+}$was consumed during the $36 \mathrm{~h}$ experiment (Fig, 1E). Negative correlations were observed between the concentrations of $\mathrm{NH}_{4}{ }^{+}$and $\mathrm{NO}_{2}{ }^{-}$for both the $<202 \mu \mathrm{m}$ plankton $\left(\mathrm{r}^{2}=0.83 ; \mathrm{p}=0.01\right)$ and the $<1.2 \mu \mathrm{m}$ plankton $\left(\mathrm{r}^{2}=0.69 ; \mathrm{p}=0.01\right)$.

The concentration of DON did not change significantly during the experiment in either size fraction. (Fig. 1C, G). Of the components of DON measured,

Table 1. Initial nitrogen concentrations and total changes in nitrogen concentrations over a $36 \mathrm{~h}$ period for the time-course conducted with size-fractionated Choptank River water in August 1990. All data are presented in $\mu \mathrm{g}$-at. $\mathrm{N}^{-1}$. The average standard deviation of nutrient values was $\pm 2.9 \%$. Standard deviations for each measurement are given in Fig. 1.

DON: dissolved organic nitrogen; PN: particulate nitrogen

\begin{tabular}{|c|c|c|c|c|}
\hline & \multicolumn{2}{|c|}{$\begin{array}{c}<202 \mu \mathrm{m} \\
\text { Concentration }\end{array}$} & \multicolumn{2}{|c|}{$\begin{array}{c}<1.2 \mu \mathrm{m} \\
\text { Concentration }\end{array}$} \\
\hline & Initial & Change & Initial & Change \\
\hline $\mathrm{NH}_{4}{ }^{+}$ & 7.60 & -7.63 & 7.60 & -6.75 \\
\hline $\mathrm{NO}_{2}^{-}$ & 5.21 & +1.79 & 4.26 & +592 \\
\hline $\mathrm{NO}_{3}$ & 1.59 & +0.87 & 2.66 & -1.07 \\
\hline DON & 26.86 & -1.55 & 25.02 & +0.56 \\
\hline PN & 17.50 & +2.45 & 3.32 & +1.68 \\
\hline Total nitrogen & 58.83 & -4.07 & 42.86 & +0.34 \\
\hline
\end{tabular}

concentrations of DPA showed a net increase of $0.33 \mu g$-at. $\mathrm{N} \mathrm{l}^{-1}$ in the $<202 \mu \mathrm{m}$ plankton but did not change significantly in the $<1.2 \mu \mathrm{m}$ plankton. Urea concentrations decreased from 0.81 to $0.35 \mu \mathrm{g}$-at. $\mathrm{N}^{-1}$ in the $<202 \mu \mathrm{m}$ plankton but increased from 0.68 to $1.46 \mu \mathrm{g}$-at. $\mathrm{N}^{-1}$ in the $<1.2 \mu \mathrm{m}$ plankton (Fig 1D, H).

A mass balance was calculated of all the measured dissolved and particulate nitrogen pools over the duration of the time-course. In the $<202 \mu \mathrm{m}$ plankton, there were $59 \mu \mathrm{g}$-at. $\mathrm{N}^{-1}$ in the measured nitrogen pools at the beginning of the experiment, but only $55 \mu \mathrm{g}$-at. $\mathrm{N}^{-1}$ at $36 \mathrm{~h}$. The amount of nitrogen present at the beginning of the experiment which could not be accounted for at each time point increased from $1.1 \mu \mathrm{g}$-at. $\mathrm{N}^{-1}(1.9 \%$ of total nitrogen) at $1 \mathrm{~h}$ to $4.0 \mu \mathrm{g}$-at. $\mathrm{N}^{-1}(6.9 \%$ of total nitrogen) at $36 \mathrm{~h}$ (Table 1 ). In contrast, in the $<1.2 \mu \mathrm{m}$ plankton, there were $42.9 \mu \mathrm{g}$-at. $\mathrm{N}^{-1}$ in the measured nitrogen pools at the beginning of the experiment and over $99 \%$ of this nitrogen was accounted for at all points throughout the time-course.

A mass balance of ${ }^{15} \mathrm{~N}$ was also performed. In the $<202 \mu \mathrm{m}$ plankton, 42 to $77 \%$ of the ${ }^{15} \mathrm{~N}$-label added at the beginning of the incubations was accounted for at the end of the incubations. In those samples where the amount of label which entered organisms $<0.7 \mu \mathrm{m}$ and which passed through the GF/F filter was measured, however, 94 to $105 \%$ of the Iabel was recovered. This suggests that organisms $<0.7 \mu \mathrm{m}$ took up either ${ }^{15} \mathrm{NH}_{4}{ }^{+}$ or recently released $D O^{15} \mathrm{~N}$ (Bronk \& Glibert in press). In the $<1.2 \mu \mathrm{m}$ plankton, however, the amount of ${ }^{15} \mathrm{~N}$ label accounted for at the end of the incubations decreased from 85 to $37 \%$ during the $36 \mathrm{~h}$ experiment. In this case, the missing ${ }^{15} \mathrm{~N}$ did not appear to enter the DON or bacterial pools. The increase in $\mathrm{NO}_{2}{ }^{-}$concentrations which occurred near the end of the experiment when the missing ${ }^{15} \mathrm{~N}$ was at its highest suggests that ${ }^{15} \mathrm{~N}$ may have been lost to the $\mathrm{NO}_{2}^{-}$pool during nitrification.

In both size fractions, all measures of biomass (chl, phaeopigment, PN) increased during the experiment, though the magnitude of the increases varied (Fig. 2). The concentration of chl increased from 3.4 to $4.8 \mu \mathrm{gg}$ chl I ${ }^{\prime}$ in the $<202 \mu \mathrm{m}$ plankton but increased by almost a factor of 4 in the $<1.2 \mu \mathrm{m}$ plankton (Fig $2 \mathrm{~A}, \mathrm{C}$ ). In the $<202 \mu \mathrm{m}$ plankton, the concentration of phaeopigments almost doubled during the $36 \mathrm{~h}$, but phatupigment concentrations remained relatively constant in the $<1.2 \mu \mathrm{m}$ plankton (Fig. 2A, C).

The initial PN: chl ratio in the $<1.2 \mu \mathrm{m}$ plankton was higher by a factor of 2 relative to the $<202 \mu \mathrm{m}$ plankton; this suggests that the $<1.2 \mu \mathrm{m}$ plankton contained a higher proportion of heterotrophs or detritus to autotrophs (Fig. 2B, D). Furthermore, the PN: chI ratios in the $<1.2 \mu \mathrm{m}$ plankton showed a pronounced decrease 


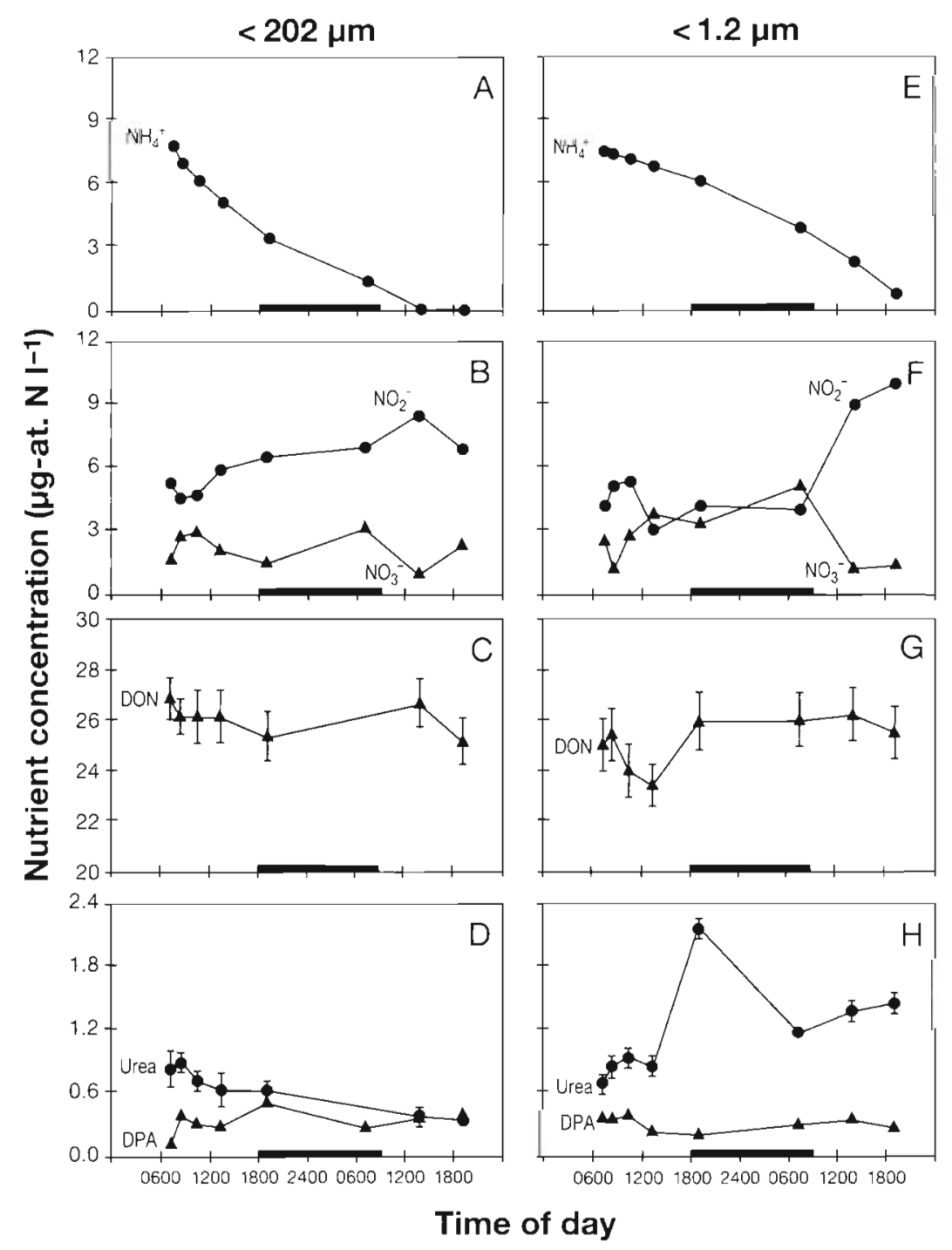

Fig. 1 The change in concentrations of $\mathrm{NH}_{4}{ }^{+}, \mathrm{NO}_{2}{ }^{-}, \mathrm{NO}_{3}{ }^{-}$, dissolved organic nitrogen (DON), urea, and dissolved primary amines (DPA) in 2 carboys with size-fractionated $(<202$ and $<1.2 \mu \mathrm{m})$ Choptank River water as a function of time of day. All concentrations are plotted with error bars indicating standard deviations. Where error bars are not shown, the standard deviations are smaller than the size of the symbol. Black bars indicate dark periods

plankton (Fig. 3B, D) and were not significantly correlated to any of the nutrient or pigment parameters measured. Rates of $\mathrm{NH}_{4}^{+}$uptake in the $<1.2 \mu \mathrm{m}$ plankton increased during the light periods but decreased during the dark (Fig. 3D). In the $<1.2 \mu \mathrm{m}$ plankton, there were positive correlations between rates of $\mathrm{NH}_{4}^{+}$uptake and chl concentrations $\left(\mathrm{r}^{2}=0.81 ; \mathrm{p}=\right.$ $0.01)$ and $\mathrm{NO}_{2}{ }^{-}$concentrations $\left(\mathrm{r}^{2}=\right.$ $0.63 ; \mathrm{p}=0.02)$.

We note that when measuring $\mathrm{NH}_{4}{ }^{+}$ uptake rates, additions of $0.66 \mu \mathrm{g}$-at. $\left.{ }^{15} \mathrm{NH}_{4}^{+}\right]^{-1}$ were made to the samples removed from the carboy, regardless of the ambient $\mathrm{NH}_{4}^{+}$concentration. The measured rates of $\mathrm{NH}_{4}{ }^{+}$uptake are therefore generally potential rates and are not directly comparable to the calculated changes in the $\mathrm{NH}_{4}^{+}$concentrations in the carboys.

\section{Rates of DON release}

In the $<202 \mu \mathrm{m}$ plankton, rates of total DON release increased from 0.03 to $0.34 \mu \mathrm{g}$-at. $\mathrm{N}^{-1} \mathrm{~h}^{-1}$ during the first $24 \mathrm{~h}$ of the experiment (Fig. 3A). In the $<1.2 \mu \mathrm{m}$ plankton, rates of total DON release ranged from 0.004 to $0.12 \mu \mathrm{g}$ at. $\mathrm{N}^{-1} \mathrm{~h}^{-1}$. Rates of DON release decreased by almost $95 \%$ during the dark period in the $<1.2 \mu \mathrm{m}$ plankton, yet in the $<202 \mu \mathrm{m}$ plankton, DON release increased by $44 \%$ during the dark (Fig. 3A, C). In the $<1.2 \mu \mathrm{m}$ plankton, rates of LMW DON release were correlated to concentrations of chl $\left(\mathrm{r}^{2}=0.86 ; \mathrm{p}=0.01\right)$.

In the $<202 \mu \mathrm{m}$ plankton, LMW DON release represented $84 \%$ of total DON

from 9.5 to $3.6 \mu \mathrm{g}$-at. $\mathrm{N} \mu \mathrm{g} \mathrm{chl}{ }^{-1}$ during the experiment, and the decrease was accompanied by a change of color on the filter from brownish green initially to bright green at the end. These observations suggest either photoadaptation of chl or possible growth of autotrophs in the $<1.2 \mu \mathrm{m}$ plankton.

\section{Rates of $\mathrm{NH}_{4}^{+}$uptake}

$\mathrm{NH}_{4}{ }^{+}$uptake rates in the $<202 \mu \mathrm{m}$ plankton were 45 to $85 \%$ higher than those measured in the $<1.2 \mu \mathrm{m}$ release at the first sampling point but then averaged $12 \pm 9 \%$ of total DON release during the remainder of the experiment (Fig. 3A). In the $<1.2 \mu \mathrm{m}$ plankton, however, rates of LMW DON release were not significantly different from rates of total DON release when tested with a 2-tailed, paired Student's t-test with a $95 \%$ confidence limit (Fig. 3C).

In the $<202 \mu \mathrm{m}$ plankton, the ratios of the rate of total DON release to $\mathrm{NH}_{4}{ }^{+}$uptake increased from 0.04 at $0 \mathrm{~h}$ to approximately 0.31 at $30 \mathrm{~h}$. In the $<1.2 \mu \mathrm{m}$ plankton, the ratios of total DON release to $\mathrm{NH}_{4}^{+}$uptake increased from 0.09 at $0 \mathrm{~h}$ to a high of 0.52 at $30 \mathrm{~h}$. 

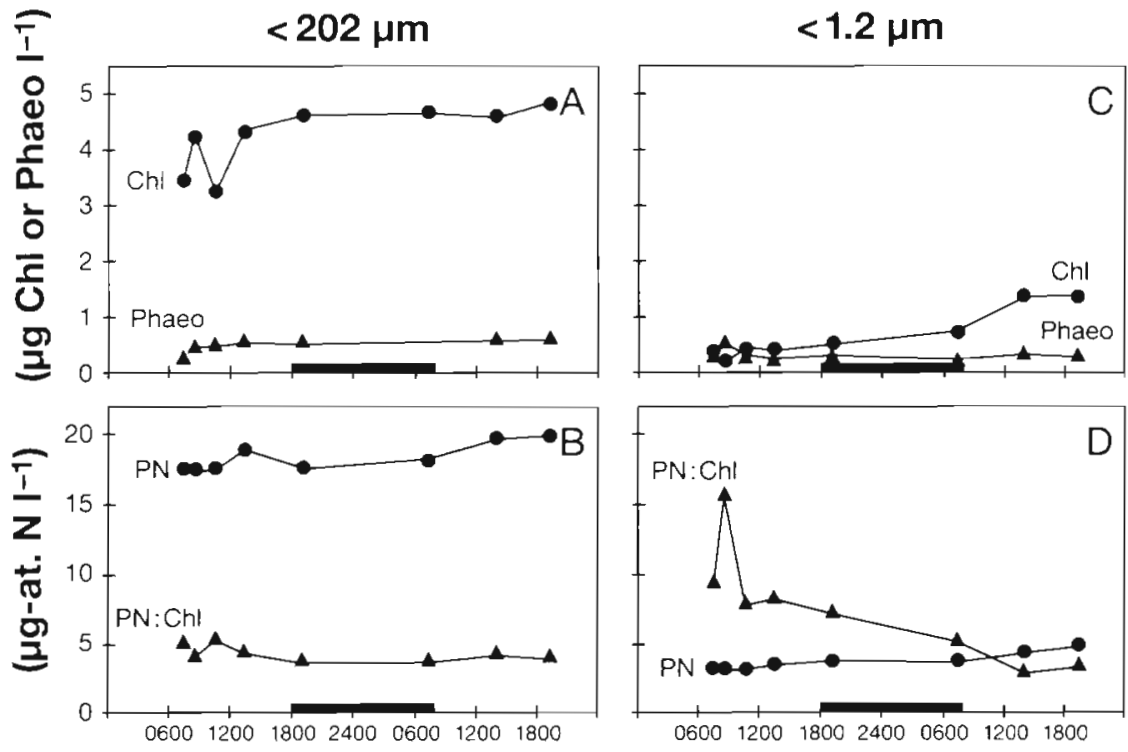

Fig. 2. The change in (A) chlorophyll a (chl) and phaeopigment (phaeo) concentrations and (B) particulate nitrogen (PN) concentrations and $\mathrm{PN}$ : chl ratios in the $<202 \mu \mathrm{m}$ plankton, and (C) chl and phaeopigment concentrations and (D) PN concentrations and PN: chl ratios in the $<1.2 \mu \mathrm{m}$ plankton, as a function of time of day. Black bars indicate dark

Time of day periods

\section{DISCUSSION}

\section{Interpretation of DON release data}

There are several potential artifacts which should be considered in DON release studies in general and this experiment in particular. First, there may have been increased rates of DON release, relative to in situ rates, due to the initial size fractionation and/or prolonged containment in the carboys. Kirchman et al. (1989) found that filtration can inflate measured rates of nitrogen release. We tried to minimize release due to filtration stress by using Nuclepore filters (Fuhrman \& Bell 1985) and gentle filtration ( $<50 \mathrm{~mm} \mathrm{Hg}$ ). Kirchman et al. (1989), however, found that release of DPA was increased even when gravity filtration was used. Gravity filtration is not an option for experiments using stable isotopes with short incubations because of the large amount of time needed to gravity filter a large enough sample for analysis.

It is also worth noting that we perturbed trophic interactions within the carboy relative to the natural field condition during the initial size fractionation, and this perturbation may have been exacerbated by the

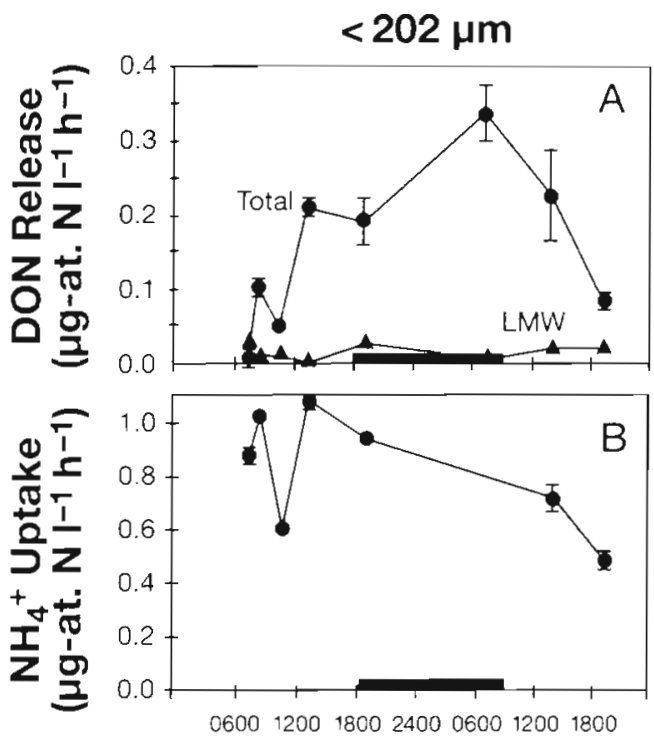

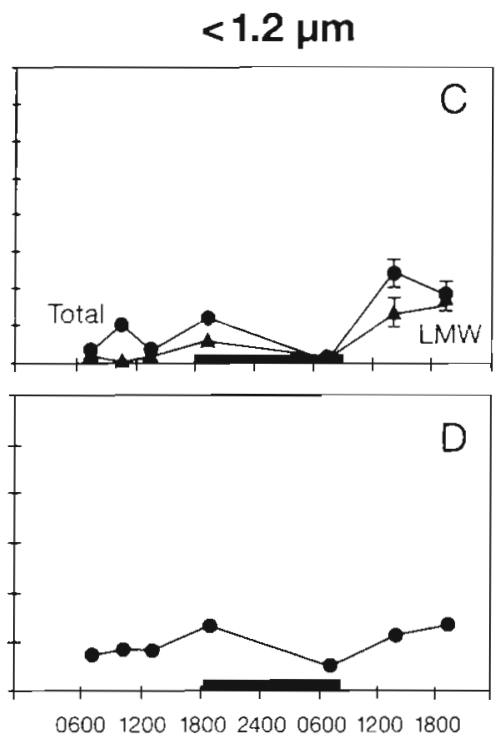

Time of day
Fig. 3. Rates of (A) total and low molecular weight (LMW; $<10000$ Dalton) dissolved organic nitrogen (DON) release and (B) $\mathrm{NH}_{4}{ }^{+}$uptake in the $<202 \mu \mathrm{m}$ plankton, and rates of (C) total and LMW DON release and (D) $\mathrm{NH}_{4}{ }^{+}$uptake in the $<1.2 \mu \mathrm{m}$ plankton as a function of time of day. All concentrations are plotted with error bars indicating standard deviations Where error bars are not shown, the standard deviations are smaller than the size of the figure. Black bars indicate dark periods 
prolonged containment (Venrick et al. 1977). These perturbations may have contributed to the increase in the ratios of DON release to $\mathrm{NH}_{4}^{+}$uptake observed in both carboys as the experiment progressed. From 0 to $3 \mathrm{~h}$ of containment the ratios of DON release to $\mathrm{NH}_{4}{ }^{+}$ uptake were 0.04 to 0.10 , which are well within the range of comparable field measurements of the ratio of DOC release to primary production (Sharp 1977 , Lancelot \& Billen 1985). By $30 \mathrm{~h}$, however, the ratios of DON release to $\mathrm{NH}_{4}{ }^{+}$uptake had increased to 0.31 and 0.53 in the $<202 \mu \mathrm{m}$ and $<1.2 \mu \mathrm{m}$ plankton respectively. Rates of $\mathrm{NH}_{4}{ }^{+}$regeneration have been shown to be higher in size-fractionated plankton samples, compared to whole plankton assemblages; the extent of this effect is in part a function of the density of the largest grazers (Glibert et al. 1992).

There are also several potential methodological problems with the ion retardation column method which could result in artificially inflated DON release rates. Selective retention of unlabeled DON compounds by the resin, or incomplete removal of ${ }^{15} \mathrm{NH}_{4}{ }^{+}$ from the DON pool prior to mass spectrometric analysis, would inflate the atom\% of the extracellular DON pool, and thus inflate the calculated rate of DON release. In extensive testing of the method, however, we found that urea, DFAA, and combined amino acids were not retained by the resin (Bronk \& Glibert 1991). Furthermore, the concentration of $\mathrm{NH}_{4}{ }^{+}$in the isolated DON fraction was measured on every sample and was found to be below the limit of detection. We did, however, correct for low levels of $\mathrm{NH}_{4}{ }^{+}$which empirical observations suggest our samples contained as described above. Similarly, if the resin selectively retained ${ }^{15} \mathrm{~N}$ labeled DON, the atom \% of the intracellular DON pool would be erroneously low, and the resulting rate of DON release would be inflated. Again, we have not observed selective retention of any of the DON compounds we tested.

\section{DON release in the $<202 \mu$ m plankton}

Possible mechanisms of DON release associated with the $<202 \mu \mathrm{m}$ plankton include excretion of DON by microzooplankton, release as a consequence of bactivory and grazing (Dagg 1974, Lampert 1978) or viral infection, and passive release by larger phytoplankton. The method used to measure rates of DON release reported here only traces the release of DON that was derived from uptake processes; it does not measure total DON flux. Therefore, direct excretion of DON by grazers, though one possible physiological mechanism of DON release, would not be included in our reported rates obtained with the tracer technique we used.
We suggest that DON release in the $<202 \mu \mathrm{m}$ plankton was most likely due to feeding processes by microzooplankton on phytoplankton or bacteria and that simultaneous uptake of recently released LMW DON may have occurred. Although we have no direct measurements of grazing in the carboys, we observed the following evidence for the impact of feeding processes on DON release. First, the percentage of total DON release which was LMW in composition was extremely small. The large percentage of high molecular weight (HMW) DON released in the $<202 \mu \mathrm{m}$ plankton suggests that release was due to some process which involves rupturing the cell, such as grazing, as a wide range of organic compounds, including compounds of HMW, would be expected to be released if cells were broken or ruptured. Alternatively, however, viral infection would also result in the rupture of cells and presumably the release of HMW DON (Proctor \& Fuhrman 1990). The fact that similarly large amounts of HMW DON release relative to total DON release did not also occur in the $<1.2 \mu \mathrm{m}$ plankton suggests that if viral infection was occurring, it was infection of the larger phytoplankton that was resulting in DON release (Cottrell \& Suttle 1991). Second, the rate of DON release increased at night when some studies have shown that grazing rates are higher (Stearns 1986, Dagg et al. 1989). Third, the concentration of phaeopigments, chl degradation products often released during grazing, almost doubled during the $36 \mathrm{~h}$ experiment (Jeffrey 1980). Finally, the ratios of DON release to $\mathrm{NH}_{4}{ }^{+}$uptake in the $<202 \mu \mathrm{m}$ plankton increased from 0.04 to 0.31 during the first $24 \mathrm{~h}$ of the experiment. The higher ratios may have been due to an increase in grazing rates of the smaller bactivores or grazer which resulted from the removal of large predators during the $202 \mu \mathrm{m}$ prescreening (Caron et al. 1991). Roman et al. (1988) observed increased predation on bacteria by heterotrophic nanoflagellates when copepods were absent.

There is also evidence that recently released DON was taken up by organisms in the $<202 \mu \mathrm{m}$ plankton. First, the appearance of ${ }^{15} \mathrm{~N}$-label in organisms 0.2 to $0.7 \mu \mathrm{m}$ indicates that these smaller organisms took up $\mathrm{NH}_{4}{ }^{+}$and/or recently released $\mathrm{DO}{ }^{15} \mathrm{~N}$. The lability of recently released DON was illustrated in a study of uptake rates of recently released DON in the mesohaline Chesapeake Bay in which we showed that during some times of year, rates of DON uptake were as high and often higher than uptake rates of $\mathrm{NH}_{4}{ }^{+}$and $\mathrm{NO}_{3}{ }^{-}$(Bronk \& Glibert 1993). Second, the ratio of LMW DON release to total DON release was only $0.13 \pm 0.09$ during most of the experiment. Though we have suggested that release of predominantly HMW DON is indicative of processes which rupture cells such as grazing or viral infection (Bronk \& Glibert 1991), one would expect that some LMW DON would be released 
during cell rupture and yet, rates of LMW DON release were often near the limit of detection. One possible scenario is that LMW DON was released but was rapidly reincorporated

\section{DON release in the $<1.2 \mu \mathrm{m}$ plankton}

In $<1.2 \mu \mathrm{m}$ plankton, most of the grazers and bactivores were removed before the experiment. In this size class, we suggest that DON release was more likely due to passive release from photosynthetic autotrophs for the following reasons. First, rates of LMW DON release were not statistically different from rates of total DON release indicating that most of the DON released was LMW in composition. Exudates from actively growing phytoplankton are often dominated by LMW compounds such as DFAA (Hellebust 1965, Wiebe \& Smith 1977). Second, rates of both total and LMW DON release were strongly correlated to changes in chl concentrations within the carboy containing the $<1.2 \mu \mathrm{m}$ plankton. Third, the PN:chl ratio decreased by a factor of 3 in the $<1.2 \mu \mathrm{m}$ plankton and the color of the filters changed from brownish green to bright green over the $36 \mathrm{~h}$, which suggests increased chl from photoadaptation or possible growth of autotrophic biomass. Finally, rates of DON release decreased by $95 \%$ during the dark period. A similar pattern of release was observed by Ward (1984), who found that phytoplankton production of ${ }^{14} \mathrm{C}$-labeled exudates was greatly reduced or zero in the dark.

\section{DON turnover}

Turnover times of total and LMW DON can be approximated by comparing ambient total and LMW DON concentrations with total and LMW DON release rates in the larger size fraction. The estimated turnover time at the first time point for total DON was $33.8 \mathrm{~d}$. A similar turnover time of $29 \mathrm{~d}$ was calculated for DOC in the mesohaline Chesapeake Bay in summer (Malone et al. 1991). The LMW DON pool had a shorter turnover time of 15.9 d which suggests that this size fraction was more labile. Turnover times based on rates of DON uptake measured in the mesohaline Chesapeake Bay in August 1991 varied from 2 to 6 d over a diel cycle (Bronk \& Glibert 1993). Measured turnover times of individual components of the DON pool are usually much shorter than those we obtained for the total DON pool. Turnover times for 4 DFAA measured in the outflow plume of Chesapeake Bay ranged from 0.02 to $0.17 \mathrm{~d}$ in August (Fuhrman 1990).

\section{Production of $\mathrm{NO}_{2}^{-}$}

There was a net production of $\mathrm{NO}_{2}^{-}$in both carboys, which was correlated to the decrease in concentrations of $\mathrm{NH}_{4}{ }_{4}$. Elevated $\mathrm{NO}_{2}^{-}$concentrations are often observed in Chesapeake Bay, particularly in late summer (McCarthy et al. 1984, Horrigan et al. 1990, Glibert unpubl. data) and these elevated concentrations have been attributed to the oxidation of $\mathrm{NH}_{4}{ }^{+}$to $\mathrm{NO}_{2}$ (McCarthy et al. 1984, Horrigan et al. 1990). Horrigan et al. (1990) measured $\mathrm{NO}_{2}^{-}$concentrations of up to $4.0 \mu \mathrm{g}$-at. $\mathrm{N}^{-1}$ and observed measurable $\mathrm{NH}_{4}{ }^{+}$oxidation to $\mathrm{NO}_{2}^{-}$in 28 out of 33 samples for which they presented data. McCarthy et al. (1984) also observed measurable oxidation of $\mathrm{NH}_{4}{ }^{+}$to $\mathrm{NO}_{2}{ }^{-}$in 8 out of 16 samples for which data were presented. It is worth noting that the importance of $\mathrm{NH}_{4}{ }^{+}$oxidation during nitrification may be undetected in some studies because $\mathrm{NO}_{2}{ }^{-}$is often not measured separately from $\mathrm{NO}_{3}^{-}$.

\section{CONCLUSION}

The 2 size fractions exhibited different patterns in rates of total DON release but were similar in the patterns in LMW DON release and in the production of $\mathrm{NO}_{2}^{-}$. The organisms in the 1.2-202 $\mu \mathrm{m}$ fraction appeared to be important agents of DON release as shown by the significantly higher rates of total DON release in the $<202 \mu \mathrm{m}$ plankton. We suggest that the higher release rates in the $<202 \mu \mathrm{m}$ plankton were the result of feeding processes such as grazing. When the larger plankton were removed, however, the relative importance of passive release of DON from photosynthetic autotrophs appeared to increase.

Acknowledgements. This research was supported by NSF grant OCE-8817585 to P. Glibert. This is contribution no. 2441 from the Center for Environmental and Estuarine Studies, University of Maryland. We thank Susan Banahan for helpful discussions and Doug Capone, Hugh Ducklow, Tom Fisher, and Carolyn Miller for reading earlier versions of this manuscript. This manuscript benefited from the comments of 2 anonymous reviewers.

\section{LITERATURE CITED}

Antia, N. J., Harrison, P. J., Oliviera, L. (1991). The role of dissolved organic nitrogen in phytoplankton nutrition, cell. biology, and ecology. Phycologia 30: 1-89

Azam, F., Fenchel, I., Field, J. G., Gray, J. S., Meyer-Reil, L. A., Thingstad, F. (1983). The ecological role of watercolumn microbes in the sea. Mar Ecol. Prog. Ser. 10: $257-263$

Bevington, P. R. (1969). Data reduction and error analysis for the physical sciences. McGraw-Hill, New York, p. 56-65 
Billen, G. (1984). Heterotrophic utilization and regeneration of nitrogen. In: Hobbie, J. E., Williams, P. J. le B. (eds.) Heterotrophic activity in the sea. Plenum Press, New York, p. 313-355

Bronk, D. A., Glibert, P. M. (1991). A ${ }^{15} \mathrm{~N}$ tracer method for the measurement of dissolved organic nitrogen release by phytoplankton. Mar. Ecol. Prog. Ser. 77: 171-182

Bronk, D. A., Glibert, P. M. (1993). Application of a ${ }^{15} \mathrm{~N}$ tracer method to the study of dissolved organic nitrogen uptake during spring and summer in Chesapeake Bay. Mar. Biol. 115: 501-508

Bronk, D. A., Glibert, P. M. (in press). The fate of the missing ${ }^{15} \mathrm{~N}$ differs among marine systems. Limnol. Oceanogr.

Brownlee, D. C., Jacobs, F. (1987). Mesozooplankton and microzooplankton in the Chesapeake Bay. In: Majumdar, S. K., Hall, L. V. Jr, Austin, H. M. (eds.) Contaminant problems and management of living Chesapeake Bay resources. The Pennsylvania Academy of Science, Philadelphia, p. 217-269

Caron, D. A., Lim, E. L., Miceli, G., Waterbury, J. B., Valois, F. W. (1991). Grazing and utilization of chroococcoid cyanobacteria and heterotrophic bacteria by protozoa in laboratory cultures and a coastal plankton community. Mar. Ecol. Prog. Ser. 76: 205-217

Chan, Y. K., Campbell, N. E. R. (1978). Phytoplankton uptake and excretion of assimilated nitrate in a small Canadian shield lake. Appl environ. Microbiol. 35: 1052-1060

Clayton, J. R. Jr, Dortch, Q., Thoresen, S. S., Ahmed, S. I. (1988). Evaluation of methods for the separation and analysis of proteins and free amino acids in phytoplankton samples. J. Plankton Res. 10: 341-358

Cottrell, M. T., Suttle, C. A. (1991). Widespread occurrence and clonal variation in viruses which cause lysis of a cosmopolitan, eucaryotic marine phytoplankter, Micromonas pusilla. Mar. Ecol. Prog. Ser. 78: 1-9

Dagg, M. J. (1974). Loss of prey body contents during feeding by an aquatic predator. Ecology 55: 903-906

Dagg, M. J., Frost, B. W., Walser, W. E. Jr (1989). Copepod diel migration, feeding, and the vertical flux of phaeopigments. Limnol. Oceanogr. 34: 1062-1071

Dolan, J. R. (1991). Guilds of ciliate microzooplankton in the Chesapeake Bay. Estuar. coast. Shelf Sci. 33: 137-152

Dugdale, R. C., Goering, J. J. (1967). Uptake of new and regenerated forms of nitrogen in primary production. Limnol. Oceanogr. 12: 196-206

Fuhrman, J. (1987). Close coupling between release and uptake of dissolved free amino acids in seawater studied by an isotope dilution approach. Mar. Ecol. Prog. Ser. 37 $45-52$

Fuhrman, J. (1990). Dissolved free amino acid cycling in an estuarine outflow plume. Mar. Ecol. Prog. Ser. 66: 197-203

Fuhrman, J. A., Bell, T M. (1985). Biological considerations in the measurement of dissolved free amino acids in seawater and implications for chemical and microbiological studies. Mar. Ecol. Prog. Ser. 25: 13-21

Glibert, P. M., Lipschultz, F., McCarthy, J. J., Altabet, M. A. (1982). Isotope dilution models of uptake and remineralization of ammonium by marine plankton. Limnol. Oceanogr. 27: 639-650

Glibert, P. M., Miller, C. A., Garside, C., Roman, M. R., McManus, G. B. (1992). $\mathrm{NH}_{4}{ }^{+}$regeneration and grazing: interdependent processes in size-fractionation ${ }^{15} \mathrm{NH}_{4}{ }^{+}$ experiments. Mar. Ecol. Prog. Ser. 82: 65-74

Hellebust, J. A. (1965). Excretion of some organic compounds by marine phytoplankton. Limnol. Oceanogr. 10: 192-206

This article was presented by J. Fuhrman, Los Angeles, California, USA
Hellebust, J. A. (1974). Extracellular products. In: Stewart, W. D. P. (ed.) Algal physiology and biochemistry. University of California Press, Berkeley, p. 838-863

Horrigan, S. G., Montoya, J. P., Nevins, J. L., McCarthy, J. J., Ducklow, H., Goericke, R., Malone, $T$ (1990). Nitrogenous nutrent transformations in the spring and fall in the Chesapeake Bay. Estuar. coast. Shelf Sci. 30: 369-391

Jeffrey, S. W. (1980). Algal pigment systems. In: Fälkowski P. G. (ed.) Primary productivity in the sea. Plenum Press, New York, p. 33-58

Kirchman, D. L., Keil, R. G., Wheeler, P. A. (1989). The effect of amino acids on ammonium utilization and regeneration by heterotrophic bacteria in the subarctic Pacific. Deep Sea Res. 36: 1763-1776

Lampert, W. (1978). Release of dissolved organic carbon by grazing zooplankton. Limnol. Oceanogr. 23: 831-834

Lancelot, C., Billen, G. (1985). Carbon-nitrogen relationships in nutrient metabolism of coastal marine ecosystems. In: Jannasch, H. W., Williams, P. J. le B. (eds.) Advances in aquatic microbiology, Vol. 3. Academic Press, London, p. $263-321$

Malone, T. C., Ducklow, H. W., Peele, E. R., Pike, S. E. (1991) Picoplankton carbon flux in Chesapeake Bay. Mar Ecol. Prog. Ser. 78: 11-22

McCarthy, J. J., Kaplan, W., Nevins, J. L. (1984). Chesapeake Bay nutrient and plankton dynamics. II. Sources and sinks of nitrite. Limnol. Oceanogr. 29: 84-98

Parsons, T R., Maita, Y., Lalli, C. M. (1984). A manual of chemical and biological methods for seawater analysis. Pergamon Press, Oxford, p. 3-22

Proctor, L. M., Fuhrman, J. A. (1990). Viral mortality of marine bacteria and cyanobacteria. Nature 343: 60-62

Roman, M. R., Ducklow, H. W., Fuhrman, J. A., Garside, C. Glibert, P. M., Malone, T C., McManus, G. B. (1988) Production, consumption and nutrient cycling in a laboratory mesocosm. Mar. Ecol. Prog. Ser. 42: 39-52

Sharp. J. H. (1977). Excretion of organic matter by phytoplankton: do healthy cells do it? Limnol. Oceanogr. 22: 381-399

Sharp, J. H. (1983). The distribution of inorganic nitrogen and dissolved and particulate organic nitrogen in the sea. In: Carpenter, E. J., Capone, D. G. (eds.) Nitrogen in the marine environment. Academic Press, New York, p. 1-35

Stearns, D. E. (1986). Copepod grazing behavior in simulated natural light and its relation to nocturnal feeding. Mar Ecol. Prog. Ser. 30: 65-76

Valderrama, J. C. (1981). The simultaneous analysis of total nitrogen and total phosphorus in natural waters. Mar. Chem. 10: 109-122

Venrick, E. L., Beers, J. R., Heinbokel, J. F. (1977). Possible consequences of containing microplankton for physiological rate measurements. J exp. mar. Biol. Ecol. 26: $55-76$

Walpole, R. E. (1970). Introduction to statistics. Macmillan, London, p. 273-277

Ward, B. B. (1984). Photosynthesis and bacterial utilization of phytoplankton exudates; results from pre- and postincubation size fractionation. Oceanol. Acta 7: 337-343

White, J. (1991). Seasonal study of zooplankton dynamics in the mesohaline Chesapeake Bay. Ph.D. dissertation, University of Maryland, p. 105-144

Wiebe, W. J., Smith, D. F. (1977). Direct measurement of dissolved organic carbon release by phytoplankton and incorporation by microheterotrophs. Mar Biol. 42: $213-223$ 